\title{
Triton's trident: cryptic Neogene divergences in a marine clam (Lasaea australis) correspond to Australia's three temperate biogeographic provinces
}

\author{
JINGCHUN LI, ${ }^{*}+$ DIARMAID Ó FOIGHIL* and JOONG-KI PARK† \\ *Museum of Zoology, Department of Ecology and Evolutionary Biology, University of Michigan, Ann Arbor, MI 48109, USA, \\ $\uparrow$ Graduate Program in Cell Biology and Genetics and Department of Parasitology, College of Medicine, Chungbuk National \\ University, Cheongju 361-763, Korea
}

\begin{abstract}
The southern coast of Australia is composed of three distinct biogeographic provinces distinguished primarily by intertidal community composition. Several ecological mechanisms have been proposed to explain their formation and persistence, but no consensus has been reached. The marine clam Lasaea australis is arguably the most common bivalve on southern Australian rocky shores and occurs in all three provinces. Here, we tested if this species exhibits cryptic genetic structuring corresponding to the provinces and if so, what mechanisms potentially drove its divergence. Variation in two mitochondrial genes (16S and COIII) and one nuclear gene (ITS2) was assayed to test for genetic structuring and to reconstruct the clam's phylogenetic history. Our results showed that $L$. australis is comprised of three cryptic mitochondrial clades, each corresponding almost perfectly to one of the three biogeographic provinces. Divergence time estimates place their cladogenesis in the Neogene. The trident-like topology and Neogene time frame of $L$. australis cladogenesis are incongruent with Quaternary vicariance predictions: a two-clade topology produced by Pleistocene Bass Strait land bridge formation. We hypothesize that the interaction of the Middle Miocene Climate Transition with the specific geography of the southern coastline of Australia was the primary cladogenic driver in this clam lineage. Additional in-depth studies of the endemic southern Australian marine biota across all three provinces are needed to establish the generality of this proposed older framework for regional cladogenesis.
\end{abstract}

Keywords: biogeographic provinces, bivalve, Lasaea australis, temperature gradient

Received 22 October 2012; revision received 14 December 2012; accepted 18 December 2012

\section{Introduction}

Despite a growing body of literature devoted to deciphering the mechanisms of speciation, our knowledge of marine speciation processes remains limited (Palumbi 1994; Barber 2009; Puebla 2009; Miglietta et al. 2011). The lack of absolute barriers in the marine realm and the prevalence of planktotrophic larval development challenges the classic view that vicariant speciation plays a predominant role in species diversification (Knowlton 1993; Palumbi 1994; Mikkelsen 2011).

Correspondence: Jingchun Li, Fax: (734) 763-4080;

E-mail: jingchun@umich.edu
Alternative models, such as speciation via ecological divergent selection (i.e. ecological speciation) (Schluter 2001; Rundle \& Nosil 2005), have been proposed to explain restricted gene flow and local divergence of taxa with high dispersal potential (Appelbaum et al. 2002; Munday et al. 2004; Puebla 2009).

The existence of marine biogeographic provincesregions composed of evolutionary distinct biotas-has been recognized and studied for more than a century (Forbes 1856; Ekman 1953; Briggs 1974; Spalding et al. 2007; Briggs \& Bowen 2012). Although such provinces are typically delineated based on disjunctions in regional community composition, recent phylogeographic studies have revealed that province boundaries may 
also resemble genetic break points where latent genetic discontinuities are consistently found in morphotaxa that have continuous distributions across multiple provinces (Riginos \& Nachman 2001; Barber et al. 2002; Teske et al. 2009). Such concordant genetic disjunctions in regions without absolute barriers often indicate the presence of latent impediments to gene flow (Avise 1992; Barber et al. 2006). Two major categories of latent barriers have been proposed: historical barriers and contemporary soft (invisible) barriers (Briggs 1974; Schopf 1979; Palumbi 1994; Liu et al. 2007; Luiz et al. 2012). The former represent absolute barriers formed through past geological events but can no longer be observed in modern environments. For example, sea level drops during Pleistocene glacial maxima were known to generate vicariant land bridges that separated marine populations and promoted genetic divergence (Reeb \& Avise 1990). The latter represents existing environmental characteristics that reduce the dispersal of certain marine organisms (Palumbi 1994). Such barriers may include the lack of suitable habitats (Hidas et al. 2007), strong current dynamics (Knox 1963) and steep gradients in sea surface temperature or salinity (Hutchins 1947). Historical barriers promote lineage diversification via the classic allopatric model, while soft barriers can also give rise to ecological speciation (Teske et al. 2011). Nonetheless, both mechanisms are likely to interact with each other and to collectively shape regional community compositions.

The high dispersal potential of many marine taxa often makes it difficult to track population diversification processes, as those taxa can sometimes span vast geographic ranges (Duda \& Lessios 2009). To better evaluate how historical and/or contemporary barriers affect marine taxa diversification on evolutionary timescales, we need to identify biogeographic break points within a regional biota characterized by a high degree of endemism. The temperate coastal biota of southern Australia represents such a study system because of its well-documented endemicity (Knox 1963; Wilson \& Allen 1987; McNeil 1994). In addition, it contains three long-recognized biogeographic provinces along a continuous coastline (Hedley 1904; Bennett \& Pope 1953, 1960; Knox 1963): Peronia (southeast), Maugea (Tasmania and southern Victoria) and Flindersia (south -west) (Fig. 1). These were initially characterized on the basis of qualitative faunal distribution patterns and physical parameters (Bennett \& Pope 1953, 1960; Rowe \& Vail 1982) but have more recently been validated by quantitative biogeographic studies ( $\mathrm{O}^{\prime} \mathrm{Hara} \&$ Poore 2000; Waters et al. 2010). Cryptic genetic breaks at province boundaries have been detected among a taxonomically heterogeneous subsample of continuously distributed morphospecies (Billingham \& Ayre 1996;

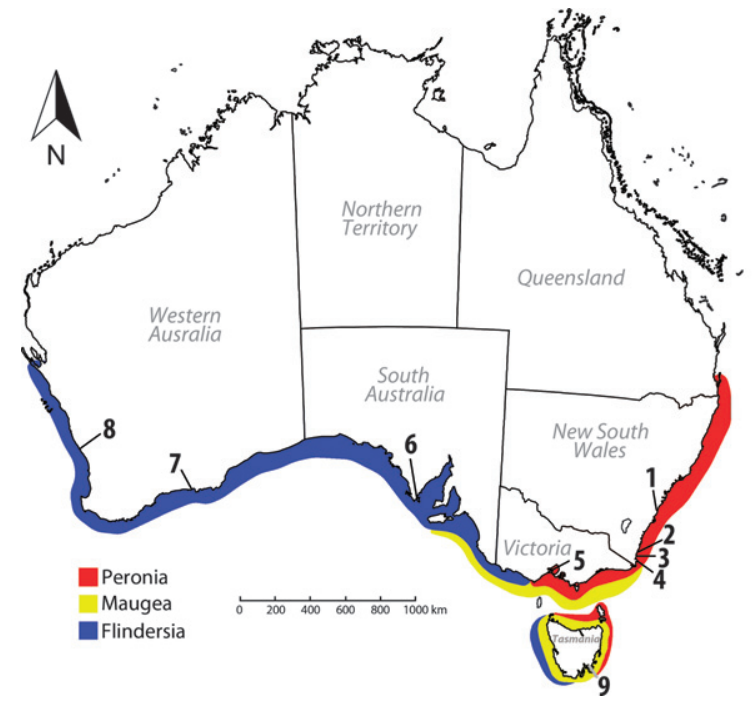

Fig. 1 Map of Australia showing the three biogeographic provinces and the study sampling locations (biogeographic province placements after Bennett \& Pope 1953). The sampling locations were as following: 1: Sydney; 2: Tura Head; 3: Haycock Headland; 4: Green Cape; 5: Jan Juc Beach; 6: Port Lincoln; 7: Esperance; 8: Guilderton; 9: Tasmania.

Kassahn et al. 2003; Waters \& Roy 2003; Dawson 2005; York et al. 2008), although many studies have focused on the East/West disjunction only (Billingham \& Ayre 1996; Burridge 2000; Dawson 2005; Waters et al. 2005).

No general consensus has been reached on what mechanisms drove the population divergences among the provinces, and they are likely to be taxa-specific (Burridge 2000). Both historical and contemporary isolation mechanisms have been proposed. The historical barrier hypothesis states that the emergence of the Bass Isthmus, a land bridge connecting Tasmania to Victoria during glacial maxima (Lambeck \& Chappell 2001), promoted east-west allopatric population divergence (Dartnall 1974), and this has been supported by phylogeographic patterns of multiple coastal taxa (Dartnall 1974; Knox 1980; Waters \& Roy 2003; Dawson 2005; Waters 2008; York et al. 2008). However, the land bridge alone cannot explain the existence of a distinct Maugean region, which includes the coastline of Victoria and Tasmania. It has been proposed that unsuitable habitats, such as the Ninety Mile Beach (Fig. 2) in southeastern Victoria, may block dispersal for some rocky shore species and promote population divergence between the Peronian and Maugean region (Hidas et al. 2007). Alternatively, it has been argued that oceanographic currents and sea surface temperature gradient may have played roles in the formation and maintenance of genetic disjunctions among the three provinces (Fig. 2) (Bennett \& Pope 1953, 1960; Knox 1963; O'Hara \& Poore 2000; Dawson 2005). On the east coast of southern Australia, the tropical-origin east 


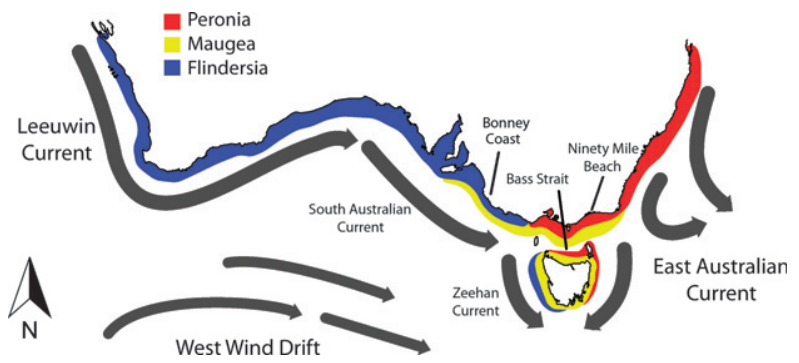

Fig. 2 Major current systems of the southern Australian coast (after James \& Bone 2010).

Australian Current flows south into the Tasmania Sea and veers offshore around Sydney, but sometimes can extend further south to Tasmania (Knox 1963; Wilson \& Allen 1987; Ridgway \& Hill 2009). On the west coast, the warm, southwards-flowing Leeuwin Current turns eastwards into the Great Australian Bight and connects with the south Australian Current and then is replaced by the cooler southwards Zeehan current near Bass Strait and Tasmania (Baines et al. 1983; Rochford 1986; Wilson \& Allen 1987; James \& Bone 2010). The circumpolar West Wind Drift is responsible for the intrusion of cold-water mass into Bass Strait, bringing cooltemperate elements into southern Australia (Wilson \& Allen 1987). In addition, extensive coastal upwelling along the west coast of Victoria and east South Australia (Bonney Coast) during the austral summer also brings cooler water towards the ocean surface in the Maugean province (Kämpf et al. 2004; Middleton \& Bye 2007). A sharp sea surface temperature (SST) drop in the Maugean region has been documented (Bennett \& Pope 1953, 1960), possibly resulting from the combination of coldwater body influence and the latitudinal temperature gradient. This could potentially act as an isolating factor for taxa that have narrow temperature/salinity tolerance. In fact, there is strong evidence that the Maugean province is mostly composed of typical cool-temperate taxa, while the other two provinces harbour warm-temperate taxa (Bennett \& Pope 1953, 1960).

The temperate Australian coast harbours a small endemic clam species, Lasaea australis (Lamarck, 1818). It is arguably the most common bivalve in the temperate Australian rocky intertidal fauna (Tong 1990) and occurs in all three biogeographic provinces, nestled in rock crevices, under coralline algae or among encrusting epifauna (Roberts 1984; Ó Foighil 1989; Ó Foighil \& Thiriot-Quievreux 1999). L. australis is the only member of the near-cosmopolitan genus Lasaea known to have planktotrophic larval development. All others are direct developers that release crawl-away juveniles (Ó Foighil 1989) and they are primarily composed of asexual clonal lineages (Ó Foighil \& Smith 1995, 1996; Ó Foighil \& Thiriot-Quievreux 1999; Taylor \& Ó Foighil 2000). The global collective range of direct developing congeners has been attributed to long distance rafting: asexual clams that release nonpelagic juveniles are more likely to turn a rare rafting event into a successful colonization than are sexual congeners with obligate planktotrophic larval development (Ó Foighil 1989; Ó Foighil \& Jozefowicz 1999).

Because of its endemicity to temperate Australian shores, its ecological prevalence there, its pelagic larval development and the availability of a global generic phylogenetic framework (Taylor \& Ó Foighil 2000), we consider Lasaea australis to be a model exemplar taxon to investigate marine genetic diversification along the southern Australian coast. Our primary questions in this study concern whether L. australis exhibits cryptic genetic structuring corresponding to the three regional biogeographic provinces, and if so, what mechanisms may have promoted this diversification.

\section{Materials and methods}

\section{Specimen collecting}

Live Lasaea australis were sampled from intertidal crevices at nine locations along the southern coast of Australia and from eastern Tasmania (Fig. 1) and preserved in $95 \%$ ethanol by a variety of collectors over a 16-year period-see Table S1 (Supporting information) for details. Four of these locations were located in the Peronian Province (1-4), two in the Maugean Province $(5,9)$ and three in the Flindersian Province (6-8). Note that the 22 Tasmanian individuals were collected from five localities; but because four of the five contributed only one individual each, we considered all Tasmanian individuals as representing one Maugean population in population genetic analyses. Two direct developers from Sydney Harbour, Lasaea colmani and an unidentified Lasaea species, were also collected to be added to the global Lasaea phylogeny. Specimens of congeneric direct developers from Hong Kong, that place sister to L. australis in molecular phylogenies, were collected from intertidal rocky shores of Shek O, Hong Kong by the first author.

\section{DNA amplification}

Genomic DNA was extracted from mantle tissue or from the whole animal using the Omega Biotek E.Z.N.A. Mollusc DNA kit (Omega tech). Fragments of two ribosomal genes, the mitochondrial (mt) large subunit $16 \mathrm{~S}$ and the nuclear internal transcribed spacer 2 (ITS2), were used to investigate the population genetic structure of L.australis. The target 16S fragment was initially amplified using the universal primer set 16Sar/ 
16Sbr (Kessing et al. 1989). For templates that failed to amplify, a Lasaea-specific primer set 16SLasF (5'-TAG ATTAAGGGTTGGGCCTG-3')/16SLasR(5'-GCCTAAATGGTAAGACTGTT-3') was developed and used to increase the success rate. A touchdown PCR protocol was used for both primer sets. The initial annealing temperature was $55^{\circ} \mathrm{C}$; it was decreased by $2{ }^{\circ} \mathrm{C}$ per cycle until the final annealing temperature $\left(48^{\circ} \mathrm{C}\right)$ was reached, and then the reaction was continued for an additional 35 cycles. Gene fragments were successfully amplified from 107 L. australis individuals and eight Lasaea sp. (Hong Kong) individuals. All PCR products were either sequenced on an ABI 377 automated DNA sequencer (Perkin-Elmer) or at the University of Michigan Sequencing Core facility. GenBank Accession nos of all unique sequences are provided in Table S1 (Supporting information). Sequences were aligned using ClustalW (Thompson et al. 1994) implemented in CodonCode Aligner 3.1.7 and corrected by eye. The 16S gene segments amplified using Lasaeaspecific primers $(388 \mathrm{bp})$ were shorter than the ones using universal primers ( $500 \mathrm{bp})$. The homologous 388-bp fragment was used for further analysis.

The 16S data set indicated that many individuals shared identical haplotypes; thus only a subset $(N=29)$ of the templates from representative locations was selected for nuclear marker characterization. There was a complication for locations 1, 6 and 9 in that mitochondrial genotyping (16S \& COIII) was performed 12 years ago (by the third author). The entire clams were used to prepare DNA templates, and the templates were degenerated by accident in later years. Therefore, we no longer have tissue samples or DNA templates from those specimens anymore. In these cases, additional specimens $(N=17)$ from location 1,6 and 9 (or nearby locations) were used for generating new DNA templates for the subsequent ITS2 PCR. The ITS2 fragment (453 bp) was amplified using the combination of two sets of primers: the universal primers ITS2F/ITS2R (Xu et al. 2001) and a Lasaea-specific primer set LasITS2F (5'-CAATGTGGTCTGCAATTCAC-3')/LasITS2R (5'-GG AATCCTAGTTAGTCTC-3'). A standard PCR protocol with an annealing temperature at $52{ }^{\circ} \mathrm{C}$ was adopted. PCR products were sequenced and aligned as described for the $16 S$ gene.

Another mitochondrial gene, cytochrome oxidase III (CO III, $624 \mathrm{bp}$ ), was used to put L. australis mt lineages from all three provinces into a global phylogenetic framework (Ó Foighil \& Jozefowicz 1999; Taylor \& Ó Foighil 2000). L. australis $(N=9)$, L. colmani $(N=1)$ and the unidentified Sydney Harbour direct developer 'LundSdy' $(N=2)$ were genotyped using the primer set COIIILas1/COIIILas2 (Ó Foighil \& Smith 1995) following a 35-cycle touchdown PCR protocol. The initial annealing temperature was $52{ }^{\circ} \mathrm{C}$ and was decreased by $2{ }^{\circ} \mathrm{C}$ per cycle until the final annealing temperature $\left(42{ }^{\circ} \mathrm{C}\right)$ was reached. PCR products were sequenced as previously described. Previously published COIII sequences $(N=29)$ for one L. australis individual, congeneric Lasaea taxa and the outgroup Kellia laperousi (see details in Ó Foighil \& Jozefowicz 1999; Taylor \& Ó Foighil 2000) were downloaded from GenBank and aligned with Lasaea sequences obtained in this study. The quality of the first $12 \mathrm{bp}$ and last $13 \mathrm{bp}$ of the alignment was poor and these parts of the alignment were eliminated from the phylogenetic analysis. The final size of the COIII gene segment used in this study was 598 bp.

\section{Molecular and phylogenetic analyses}

We used JModelTest 2.0 (Darriba et al. 2012) to calculate likelihood scores of different substitution models for the mt $16 S$ data sets. Models were ranked according to the Bayesian information criterion (BIC). Specific models used in different analyses were chosen based on their respective BIC rankings and their model availabilities in the software.

A hierarchical Analysis of Molecular Variance (AMOVA) was performed using Arlequin 3.5 (Excoffier \& Lischer 2010) on the mt16S data set to evaluate degrees of genetic variance within and among the three provinces. Individuals from Tura Head, Haycock Headland and Green Cape (Fig. 1, locations 2-4) were combined into one population because these locations are geographically close (within $50 \mathrm{~km}$ ). Populations were then assigned into three groups, representing the three biogeographic provinces, respectively. The Tamura 3-parameter model (Tamura 1992) with a gamma distribution $(G=0.16)$ was used to calculate genetic distances between haplotypes. The variance components and $\Phi$ statistics were calculated for among provinces, among populations within provinces and within populations, respectively. A null distribution of the haplotypes was generated through 10100 permutations and the probability of obtaining a larger variance component than the observed value by chance (i.e. $P$ value) was obtained for all three sources of variance. The mean genetic distances among and within the three groups were calculated in MEGA 5.0 (Tamura et al. 2011) using the same substitution model.

Both Bayesian and maximum-likelihood (ML) inferences were used to reconstruct the within-species phylogeny of L. australis using the $16 \mathrm{~S}$ data set. Identical haplotypes were removed from the alignment, leaving only unique haplotypes in the data set. The Bayesian analysis was performed using MrBayes 3.2.0 (Ronquist \& Huelsenbeck 2003). The best-fit model selected by 
JModelTest using BIC was HKY+G (Hasegawa et al. 1985). However, the next best model TPM3uf $+\mathrm{G}$ (Posada 2008) had a very similar log-likelihood score. We therefore chose not to set up a prior substitution model, but to use the 'mixed' model (+G) implemented in MrBayes 3.2.0, which allows MrBayes to move across different substation schemes as part of its MCMC sampling to account for uncertainty concerning the correct substitution model (Ronquist et al. 2012). We also did the same analysis only using the HKY+G model, so the results can be compared. The Markov chain Monte Carlo (MCMC) was run for two million iterations with trees sampled every 1000 interactions. Two cold and two heated chains were used in each run, and two independent runs were performed. The cumulative split frequencies were confirmed to be below 0.01. All parameters were examined in Tracer v1.5 (Rambaut \& Drummond 2009) to ensure convergence and proper mixing. The first 500 trees were discarded as burn-in and a $50 \%$ majority consensus tree was obtained. The maximum-likelihood analyses were conducted with 100 bootstrap replicates using the RAXML (Randomized Axelerated Maximum Likelihood) 7.2.8 (Stamatakis et al. 2008) online serves hosted at the T-Rex (Tree and Reticulogram Reconstruction, Alix et al. 2012) web server (www.trex.uqam.ca.). The best scoring tree was selected to represent the phylogeny.

Because the ITS2 data set includes very few phylogenetically informative sites (4/453 bp), we constructed a haplotype network to visually represent the population genetic structure of L. australis. The ITS2 sequences of three individuals (out of 46 individuals) genotyped for this marker exhibited heterozygotic profiles in certain sites, which suggest intragenomic variation for the ITS2 gene. It is known that ribosomal genes can have hundreds of copies within a genome (Sánchez \& Dorado 2008). There are cases (including marine bivalves) where multiple ITS2 haplotypes were found within one genome (Sánchez \& Dorado 2008; Vierna et al. 2010). Therefore, to avoid arbitrarily selecting one haplotype over another, all sequences were phased using PHASE 2.1.1 (Stephens et al. 2001). Note that the above step is only to separate two possible haplotypes from the heterozygotic sequences. The homozygotic sequences were also phased simply to maintain the proper haplotype frequencies. Haplotype network of all phased sequences were subsequently constructed in TCS 1.21 (Clement et al. 2000).

We used BEAST 1.7.1 (Drummond et al. 2012), together with fossil record and molecular clock calibrations, respectively, to estimate the divergence times among the three L. australis $\mathrm{mt}$ lineages analysed within the available global generic mt COIII data set (Taylor \& Ó Foighil 2000). Substitution models and partition scheme of the COIII gene were simultaneously selected according to BIC using the program PartitionFinder (Lanfear et al. 2012). The TrN+G model (Tamura \& Nei 1993) was selected for the first and third codon positions and the $H K Y+G$ model was selected for the second codon position.

The marine bivalve fossil record (Jablonski et al. 2003) indicates that the divergence time between Lasaea and its closely related genus Kellia (used as an outgroup) is approximately $\geq 51.9$ Mya. We therefore applied this calibration point by offsetting the root height of the $\mathrm{mt}$ COIII phylogeny by 51.9 Myr [prior distribution = lognormal, mean $=3, \log (\mathrm{SD})=0.75]$. We assumed an uncorrelated lognormal distribution for the molecular clock and the Yule process for the speciation model. Codon partition and substitution models were set according to the scheme selected by PartitionFinder. Default prior distributions were used for other parameters. Two independent MCMC analyses were run for 10 million iterations respectively and sampled every 1000 iterations. Convergence diagnostics were conducted in Tracer v1.5 (Rambaut \& Drummond 2009) and reliable ESS values $(>200)$ were ensured. Trees from the two MCMC runs were combined using LogCombiner (Drummond et al. 2012) with the first 1000 trees discarded as burn-in respectively; the maximum credibility tree was generated from the combined trees in TreeAnnotater (Drummond et al. 2012).

There are a number of well-known problems with the fossil calibration approach that may also apply to this study, such as inaccurate fossil record and rate heterogeneity across the phylogeny, etc. To compensate for these uncertainties, we also performed the same analysis using a calibrated molecular clock method. There are currently no available calibrations for the mollusk COIII gene and we applied available calibrations for the mt COI gene of ark clam species (Marko 2002). Marko (2002) estimated the sequence divergence rate for COI in three partitions: 1 st + 2nd codon positions, 3rd position only and all sites. Because mt COIII allows relatively more amino acid substitutions among closely related species than mt COI gene (Ó Foighil \& Smith 1995), it exhibits a higher rate of 1st and 2nd codon position changes. We therefore applied two dating strategies: the ark clam $\mathrm{mt} \mathrm{COI}$ overall divergence rate to the whole Lasaea mt COIII data set; the ark clam COI 3rd codon position rate to a Lasaea COIII 3rd codon positions only data set. Detailed prior settings for the molecular clocks are shown in Table 1. Note that sequence divergence rate $=$ substitution rate $\times 2$ (Wilke et al. 2009). Thus, the mean substitution rates defined in our analyses were obtained by dividing the mean sequence divergence rates in Marko (2002) by two. Also, Marko (2002) used three calibration points to 
Table 1 Two molecular clock calibrations used to estimate the divergence time of the three Lasaea australis clades. All units are per site per Myr

\begin{tabular}{lll} 
Molecular clock & Sequence divergence rates from Marko (2002) & $\begin{array}{l}\text { Substitution rates specified in BEAST } \\
\text { Prior distribution }=\text { normal }\end{array}$ \\
\hline COI third position & Mean $=5 \% \mathrm{SD}=1.3 \%$ & Mean $=2.5 \% \mathrm{SD}=0.7 \%$ \\
COI all sites & Mean $=1 \% \mathrm{SD}=0.2 \%$ & Mean $=0.5 \% \mathrm{SD}=0.1 \%$ \\
\hline
\end{tabular}

calculate the divergence rate, respectively, for each partition; here, we take the mean of the three rates to represent the sequence divergence rate of each partition scheme.

\section{Results}

Analysis of mt $16 S$ molecular variance

The 107 Lasaea australis individuals genotyped for the mt 16S marker yielded 44 unique haplotypes: 11 Peronian, 23 Maugean and 10 Flindersian. No two provinces shared the same haplotype. Results from the hierarchical AMOVA are shown in Table 2. Among-province variance accounts for the overwhelming majority (94\%) of total genetic variation across the species' range. A modest amount of within-population heterogeneity was also detected, but very little phylogenetic structure was found among populations within the same province. The mean genetic distances (substitutions per site) among the three groups are the following: 10.3\% (Peronian/Maugean), $11.4 \%$ (Peronian/Flindersian) and 9.9\% (Maugean/Flindersian). And the mean distances within the groups are as follows: $0.4 \%$ (Peronian), 0.9\%(Maugean) and $0.2 \%$ (Flindersia).

\section{mt 16S Phylogeny}

Results for the 16S phylogeny are shown in Fig. 3a. Both Bayesian and ML analyses yielded congruent topologies. Bayesian analyses using the 'mixed' model and the $\mathrm{HKY}+\mathrm{G}$ model both showed the same topology. The Baysian consensus tree is shown here (see Fig. S1, Supporting information for the complete phylograms). Three well-supported clades are observed, each corresponding to one of the biogeographic provinces. L. australis individuals from each province form their own monophyletic groups, except for one Maugean clam (Jan Juc Beach origin, Fig. 3a, asterisk), whose haplotype placed unambiguously in the Flindersian clade. The Maugean and the Flindersian clades are derived sister lineages in this phylogeny, but the ML bootstrap value (63\%) for this node is relatively low, which indicates a possibility of polytomy. No well-supported subclade structuring was recovered within the topology of any of the three provincial clades.

\section{ITS2 Halpotype network}

A total of 46 individuals were successfully amplified for the ITS2 gene fragment. Because three individuals from the Flindersian province produced heterogeneous sequences, the whole data set was phased to separate these haplotypes. Ninety-two haplotypes were obtained as a result, and seven unique haplotypes are present in the populations.

Three most common haplotypes were detected (Fig. 3b, P, F and FM). Haplotype P is shared exclusively among the 14 Peronian individuals typed for this marker. Haplotype $\mathrm{F}$ is shared by seven Flindersian individuals. Haplotype FM, however, is shared by all 13 Maugean individuals and 10 Flindersian individuals (including two heterozygous individuals). Of those 10 Flindersian individuals, nine were sampled from Port Lincoln (Eyre Peninsula), a location near the boundary of Maugea and Flindersia (Fig. 3, arrow) and one individual was from a more distant location: Guilderton, on

Table 2 Results of the hierarchical AMOvA for the Lasaea australis $\mathrm{mt} 16 \mathrm{~S}$ gene. Note that slightly negative variance components are usually considered to be statistical artefacts, can occur when the true value is zero and are generally viewed as indicating a lack of genetic structuring (Caterino \& Chatzimanolis 2009)

\begin{tabular}{lccrr}
\hline Source of variation & d.f. & Variance components & \% Total variation & $\Phi$ \\
\hline Among provinces & 2 & 12.45 & 94.08 & 0.94 \\
Among populations within provinces & 4 & -0.02 & -0.21 & $<0.01$ \\
Within populations & 98 & 0.81 & 6.12 & -0.03 \\
\hline
\end{tabular}




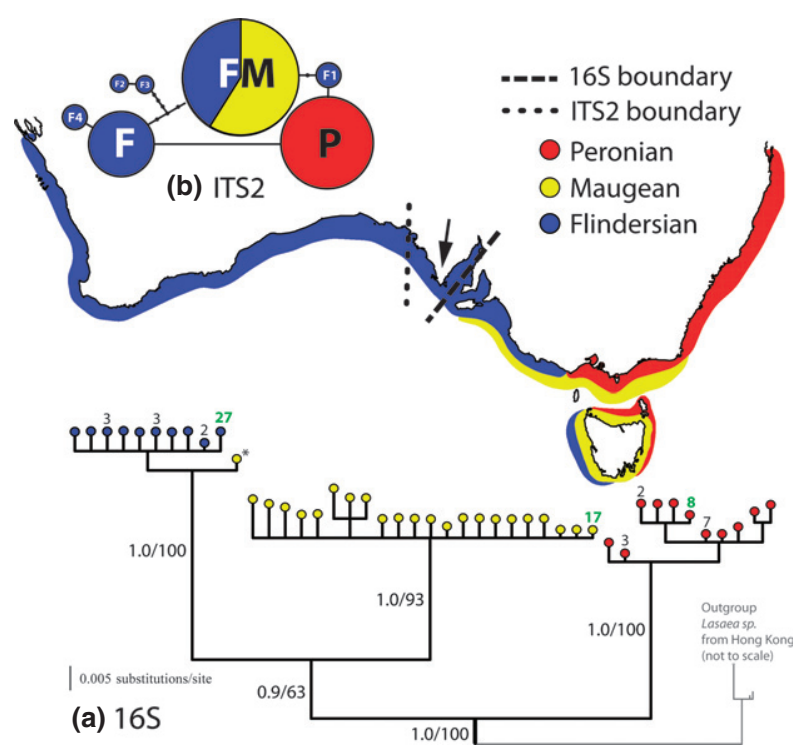

Fig. 3 (a) Bayesian mt 16S phylogeny of Lasaea australis. Clams haplotypes are colour-coded according to their biogeographic provinces of origin. Haplotype frequencies $(N>1)$ were indicated by the accompanying terminal number. Branch labels represent Bayesian posterior probabilities and maximum-likelihood bootstrap values, respectively. An ectopic Flindersian clade haplotype, recovered from a Maugean clam, is indicated by an asterisk. (b) ITS2 haplotype network. Each circle represents one unique haplotype. The size of each circle is proportional to numbers of that unique haplotype in the population and haplotypes are colour-coded according biogeographic province. Each black dot represents one inferred base pair change. The arrow on the map points out Port Lincoln on the Eyre Peninsula, where most clams shared the same haplotype as Maugean individuals. The inferred geographic boundaries between the Maugean and Flindersian lineages based on 16S (heavy dashed line) and ITS2 (light dashed line) are shown on the map, respectively.

the Indian Ocean coast of western Australia (Fig. 1, location 8). Four rare haplotypes were present in the Flindersian populations (F1-F4), three of which were present in heterozygous condition. Haplotype F1 occurred in two heterozygous individuals that also had the common haplotype FM. Haplotypes F2 and F3 were recovered from a third heterozygotic Flindersian individual. Finally, haplotype F4 was from one homozygous Flindersian individual.

\section{Divergence time estimation}

Figure 4 shows a global Lasaea phylogeny based on $\mathrm{mt}$ COIII gene sequence variation with a fossil calibration. The topology is congruent with that previously published by Taylor \& Ó Foighil (2000) except that L. colmani is now sister to another (undescribed and newly sequenced) Australian direct developer (LundSdy02-03). L. australis COIII haplotypes formed a weakly supported derived clade within the genus and they additionally formed robust, province-specific terminal clades. Unlike the mt $16 \mathrm{~S}$ topology (Fig. 3), the Peronian clade is sister to the Maugean clade here (for both fossil and COI third codon calibrations); although the support value for this relationship is quite low (0.6). However, in the phylogeny estimated using the COI all sites substitution rate (not shown), the Peronian clade is sister to the Flindersian clade with a weak support (0.4). Thus, the phylogenetic relationships among the three clades are not congruent, nor well supported, for both mt markers.

Results of the mt COIII divergence time estimations for Lasaea australis clades are shown in Table 3. Note that the fossil-calibrated nodal age estimates (Table 3, Fig. 4) are largely congruent with the mt COI-calibrated estimates for third codon positions only. Accordingly, the age estimates for the L.australis lineage divergence from the common ancestor of its sister direct-developing congeners are 17.3 Mya (fossil calibration) and $\sim 17.1$ Mya (COI third codon calibration). The respective age estimates for the divergence of the Flindersian clade from the common ancestor of the Maugean and Peronian clades are 13.4 and $~ 13.1$ Mya; ages for the Maugean/Peronian split are $\sim 12.0$ and 11.7 Mya. Divergence dates estimated based on the COI all sites rate are older. Estimated divergence age for the L. australis clade is $\sim 31.7$ Mya; the Maugean clade diverged from the other two around 24.9 Mya and the estimated age for the Peronian/Flindersian split is 20.1 Mya. The estimated COIII substitution rates for all three calibration methods are also shown in Table 3. 
Table 3 Results of the divergence time estimations based on COIII sequences for the three Lasaea australis clades. Clade names are abbreviated as following: Peronia (P), Maugea (M) and Flindersia (F). Divergence time estimates for the three calibration methods used are reported, each with a 95\% highest posterior density (HPD). Estimated substitution rates are also shown. Time units are in Mya and substitution rate units are per site per Myr

\begin{tabular}{|c|c|c|c|c|c|c|c|c|}
\hline Methods & $\mathrm{F} / \mathrm{P}+\mathrm{M}$ & $95 \% \mathrm{HPD}$ & $\mathrm{P} / \mathrm{M}$ & 95\% HPD & Lasaea australis & $95 \% \mathrm{HPD}$ & Substitution rate & $95 \% \mathrm{HPD}$ \\
\hline Fossil calibration & 13.4 & 7.7-19.6 & 12.0 & $5.5-19.0$ & 17.3 & $10.9-24.2$ & $2.0 \%$ & $1.4-2.6$ \\
\hline COI third position & 13.1 & $6.1-22.7$ & 11.7 & $4.6-20.7$ & 17.1 & $8.0-28.8$ & $2.7 \%$ & $1.3-4.0$ \\
\hline COI all sites & $\begin{array}{l}\mathrm{M} / \mathrm{P}+\mathrm{F} \\
24.9\end{array}$ & $11.1-42.4$ & $\begin{array}{l}\mathrm{P} / \mathrm{F} \\
20.1\end{array}$ & $8.3-35.3$ & 31.7 & $15.0-53.5$ & $0.5 \%$ & $0.3-0.7$ \\
\hline
\end{tabular}

\section{Discussion}

\section{Lasaea australis phylogeography}

The population genetic analyses and phylogenetic reconstructions based on the mitochondrial genes demonstrate unambiguously that $L$. australis is composed of three distinct clades that correspond with high fidelity to the three temperate biogeographic provinces of southern Australia. Although mean genetic distances among the provincial clades were pronounced, populations within each province showed little evidence of genetic differentiation. Within-provincial clade variation was dominated by one (Flindersia, Maugea) or two (Peronia) common haplotypes with assorted singletons (Fig. 3a). The pattern of $\mathrm{mt}$ lineage distribution observed is consistent with the presence of sharp cryptic genetic disjunctions between the provincial clades coupled with high levels of within-province connectivity.

The $16 \mathrm{~S}$ and COIII phylogenetic analyses yielded different sister relationships among the three provincial clades and both reconstructions recovered short internodes among the three clades relative to their respective stem branches-indicating a relatively old and rapid lineage diversification process within L. australis. Due to the incongruent $16 \mathrm{~S}$ and COIII topologies, we conservatively view the three provincial clades as a polytomy until more data can be brought to bear on this issue.

The nuclear gene ITS2 had much less sequence variation among the study populations compared with the mitochondrial genes. This is not surprising as nuclear genes tend to evolve slower than mitochondrial genes (Brown et al. 1979). In one study on marine bivalves, it has been estimated that the substitution rate of ITS2 can be 10 times slower than the mitochondrial proteincoding gene COI (Faure et al. 2009). Nonetheless, the ITS2 haplotype network largely corroborated the $\mathrm{mt}$ genetic disjunctions among the three provinces. Most of the discrepancy between results from the nuclear gene and mitochondrial genes involved one Flindersian population from Port Lincoln (Fig. 3, arrow). In the mitochondrial tree (Fig. 3a), all 20 individuals genotyped from this location belonged to the Flindersian clade, but in the ITS2 network, all nine genotyped Port Lincoln individuals shared the same haplotype (Fig. 3, FM) as the Maugean samples. Based on this nuclear marker, the genetic break between the Maugean and Flindersian lineages lies to the west of Port Lincoln; while according to the mitochondrial data, the boundary lies to the east of Port Lincoln as traditionally defined (Fig. 3).

Topological discordance between mitochondrial and nuclear genes is not uncommon (Wiens et al. 2010). They can result from incomplete lineage sorting, introgression and gene duplication/extinction events (Maddison 1997). Because the mitochondrial genome is maternally inherited and haploid, it has a smaller effective population size and experiences a faster coalescence time (Moore 1995). Therefore, we may observe complete lineage sorting for mitochondrial genes but not for nuclear markers (Zink \& Barrowclough 2008). And this is likely to be the case for L. australis. In Particular, the presence of intragenomic variation for the ITS2 gene further suggests the possibility of incomplete lineage sorting or even gene introgression. Therefore, our mitochondrial phylogenies may have a higher probability of reflecting the true lineage diversification processes in L. australis.

Up to now, Lasaea australis has been considered as a single continuously distributed southern Australian species (Taylor \& Ó Foighil 2000). The mitochondrial phylogenies strongly indicate the possibility of three cryptic species, as the genetic distances among the clades exceed the general threshold (10 times average intraspecific difference) for new species (Hebert et al. 2004). However, we did not detect any clade-specific morphological characters that can distinguish the three lineages. Thus, we consider it best to view L. australis as a cryptic species complex at present-one that requires detailed ecological and genetic study, especially at biogeographic province boundaries. 


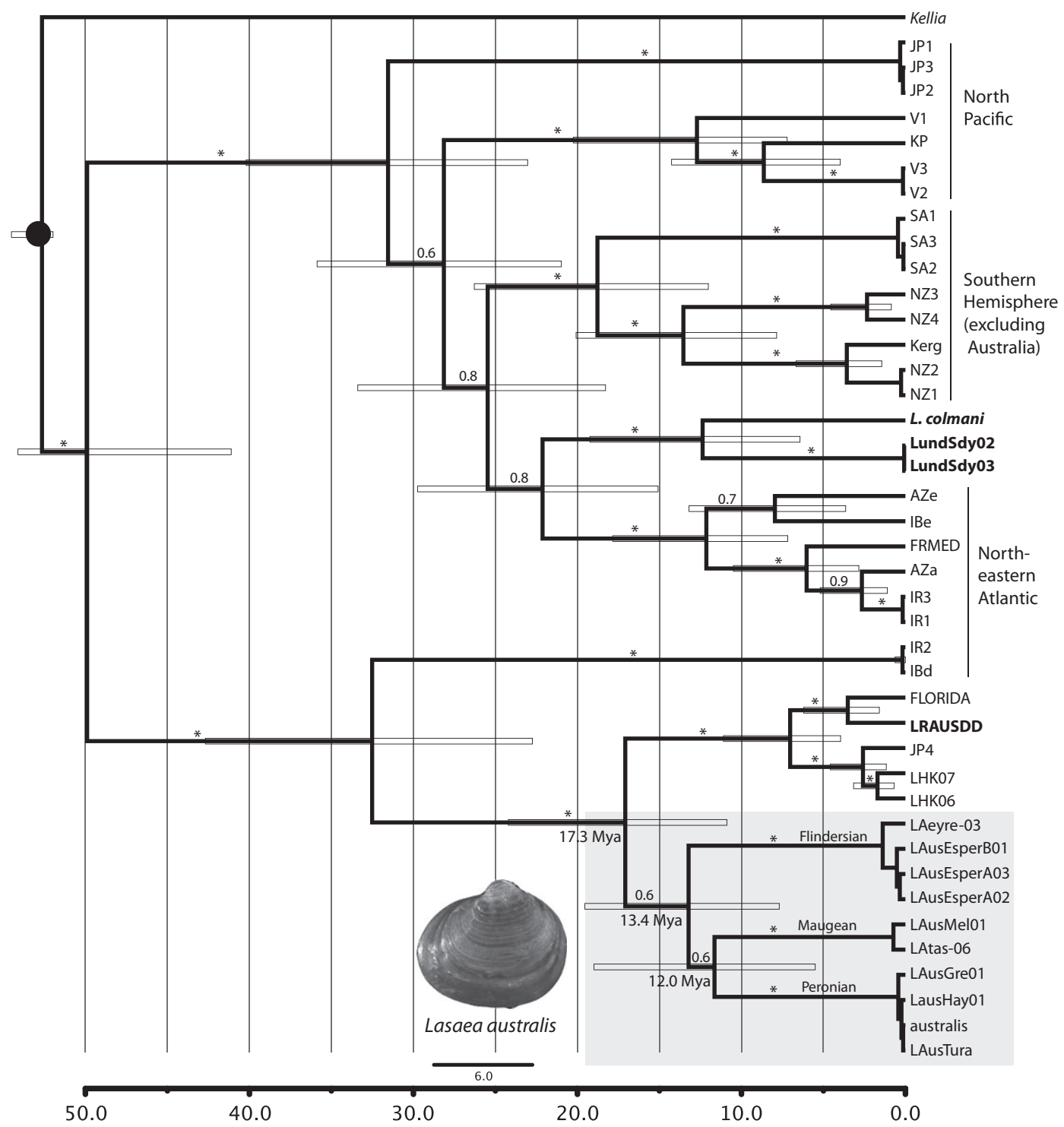

Fig. 4 BEAST divergence time estimation of global Lasaea lineages using a fossil calibration. The Lasaea australis clades are highlighted by grey shading and divergence time estimations are labelled under the branches. Posterior probabilities are shown as branch labels (1.0 is indicated by an asterisk). The fossil calibration point is indicated by a black circle. Bars on branch nodes represent $95 \%$ Highest Posterior Density age intervals. Name abbreviations of other Lasaea species see Ó Foighil \& Jozefowicz (1999). Australian directdeveloping Lasaea lineages are shown in bold. Time units are Mya. All taxa depicted are direct developers apart from L. australis and the outgroup Kellia laperousi.

\section{Diversification mechanisms}

Determining divergence times among the three provincial L. australis clades is crucial for evaluating potential diversification mechanisms. Estimates vary depending on the calibration method used (Table 3). Divergence date estimations using two independent calibration methods, fossil record and the ark clam COI third codon position rate (Marko 2002), yielded highly consistent results that the divergence time among the three L. australis lineages are around 11-14 Myr. Analysis based on the COI all sites substitution rate yielded much older dates (20-24 Myr). However, because the average substitution rate of the COIII gene is higher than the COI gene (Ó Foighil \& Smith 1995), our molecular clock analysis based on the COI all sites rate is very likely to overestimate the divergence times. In contrast, similar substitution rates can be more reasonably assumed for third codon positions (least exposed to purifying selection) of both mt genes. Thus, our estimation based on the COI third codon position rate is more likely to approach a realistic time range for L.australis 
provincial clade diversification especially that the results concur with the fossil calibrations.

The divergence times based on the fossil calibration and the COI third codon position rate both date back to the Mid to Late Miocene; a time frame that is incongruent with some of the hypotheses proposed to explain the genesis of the three biogeographic provinces. This includes the historical barrier hypothesis invoking Pleistocene glacial maxima vicariance events as diversification drivers (Dartnall 1974; Waters et al. 2004, 2005; Dawson 2005). Conservatively, even if considering the earliest age estimates obtained within the $95 \%$ highest posterior density (HPD), these Pliocene divergence times, $\sim 4.6$ and $6.1 \mathrm{Mya}$ (Table 3), still pre-date the onset of the Northern Hemisphere Glaciation ( 2.75 Mya, Ravelo et al. 2004) and the emergence of the Bass Strait land bridge. Our divergence estimates also greatly pre-date the proposed dispersal barrier at Ninety Mile Beach area, an extended sandy shore along the northeast coast of Victoria that emerged fairly recently $(<6000$ years ago) after the postglacial submergence of the east Gippsland coast (Bird 1961).

The near shore current systems around southern Australia (Fig. 2) are known to affect species dispersal and distributions (Knox 1963; Waters 2008; Ridgway \& Hill 2009) and the main current dynamics were established during Miocene (Gallagher et al. 2001). However, among-provinces dispersal of the clams are unlikely to be hindered by the currents because they touch on multiple provinces: the East Australia Current flows southwards into Peronia but can also enter Maugea as far as Tasmania (Ridgway \& Hill 2009) and the Leeuwin Current, south Australian Current and the Zeehan Current collaboratively connect Flindersia and Maugea. In addition, the strength of each current varies seasonally and is affected by relatively complicated local up/downwelling events (Rochford 1986; Middleton \& Bye 2007; Ridgway \& Hill 2009). L. australis has an irregular spawning pattern with peak summer and autumn recruitment phases, at least in western Australia (Roberts 1984). Thus, larvae could persist in the water column through much of the year and, larval dispersal is highly unlikely to be restricted to individual biogeographic provinces.

Despite rejecting several hypotheses, one important ecological factor, the sea surface temperature (SST) gradient, remains a plausible driver for the L.australis diversification, especially taking into account paleoclimate condition in southern Australia. At present, Maugea shows a significantly cooler SST than the other two provinces. An abrupt SST gradient $\left(>3{ }^{\circ} \mathrm{C}\right.$, Bennett \& Pope 1953) occurs at provincial boundaries and is associated with a significant turnover in species richness and composition ( $\mathrm{O}^{\prime}$ Hara \& Poore 2000). However, the steep SST gradient was not formed until the Middle Miocene Climate Transition (MMCT, 14.2-13.8 Mya), which marked one of the major steps in Cenozoic climate evolution (Flower \& Kennett 1994; Shevenell et al. 2004). Prior to the MMCT, southern Australian waters during the Early Miocene warm phase and the Miocene Climatic Optimum (MCO, 17-14 Myr) exhibited a much warmer and more uniform temperature regime (Gallagher et al. 2001). The MCO ended with a rapid climate transition characterized by major growth of the east Antarctic ice sheets, Antarctic cooling and intensification of Southern Ocean circulation (Flower \& Kennett 1994; Holbourn et al. 2004; Shevenell et al. 2004). The meridional temperature gradient in southern Australia was greatly increased and zonality was strengthened (Gallagher et al. 2001).

Formation of the SST gradient, and associated cooling of the Maugean region, approximately corresponds to the estimated divergence time among the L. australis clades (Fig. 4). We propose that this cooling process partitioned the coastline into two warm-temperate zones (the future Flindersia \& Peronia) separated by a new cold-temperate zone (the future Maugea). We assume that the ancestral L. australis population had a continuous distribution along the coastline and that selective pressure associated with the formation of the cold-temperate zone promoted the evolution of a coldadapted southern population: the present-day Maugean clade. Meanwhile, the two disjunct warmadapted eastern (Peronian) and western (Flindersian) clades started to diverge due to isolation, yielding the characteristic trident topology (Fig. 3). At present, the cooler waters around Tasmania may still act as invisible ecological barriers that prevent the two warmer province lineages from colonizing the Maugean region and the Maugean lineage from expanding northward. Testing the temperature boundary hypothesis would require intensive sampling across provincial boundaries and transplantation experiments among the different L. australis clades. This hypothesis also allows us to infer past distributions of these lineages based on the SST paleorecord (See Fig. S2 and Table S2, Supporting information for details).

From a marine biogeographic perspective, the temperate coastline of Australia is a fascinating nearshore evolutionary setting. Unlike better-studied marine faunal transition points, such as the Gulf-Atlantic disjunction in peninsular Florida (Avise 1992, 2000), it contains not one, but two sharp genetic breaks, associated with three biogeographic provinces. The challenge to biogeographers is to provide a plausible general mechanism that explains the formation of these three geographically proximate distinct provinces along a contiguous continental coastline. 
The emergence of the Bass Strait land bridge has been frequently proposed to explain the existence of an 'Eastern' and a 'Western' clade in various marine invertebrates, such as cnidarians (Billingham \& Ayre 1996; Dawson 2005), cuttlefish (Kassahn et al. 2003), gastropods (Brown 1991; Waters et al. 2005; Colgan \& Schreiter 2011), sea stars (Waters \& Roy 2003; Waters et al. 2004) and barnacles (York et al. 2008). However, many of the studies only focused on one or two of the provinces (Brown 1991; Billingham \& Ayre 1996; Dawson 2005; Waters et al. 2005). Thus, the 'two' distinct clades could potentially represent a Peronian/Maugean, a Peronian/Flindersian or a Maugean/Flindersian disjunction. Studies that sampled across the entire coastline have typically found three provincial clades that form similar phylogenetic topologies to that of L. australis (Kassahn et al. 2003; Waters \& Roy 2003; Waters et al. 2004). Although the Bass land bridge may well be responsible for the allopatric diversifications of some regional marine organisms, that particular vicariant process can only produce geminate clades. It is not sufficient to explain a rapid formation of three distinct lineages in some taxa and the community level differentiation of three biogeographic provinces. In addition, some of the estimated divergence dates pre-date the emergence of the land bridge [i.e. 5-6 Mya for the snail Nerita (Waters et al. 2005); 7-10 Mya for cirrhitod fishes (Burridge 2000); up to 36 Mya for certain limpets in the genus Siphonaria (Colgan \& Costa 2012)]. Waters et al. (2004) suggested that those deeply divergent lineages could be the result of glacial isolations in central coastal regions, but no supporting evidence has been provided.

Our case study of L. australis highlights the fact that the SST gradient in the southern Australia is formed during the Miocene Climate Transition and that its interaction with the unique geometry of the coastline (the southern protruding landmasses of Victoria and Tasmania) made it possible to have one southern 'cold' province separating two northern 'warm" provinces. This unique geographical/ecological interaction could potentially be the primary long-term driver for marine fauna diversification in southern Australia, ultimately resulting in the well-documented province-specific community compositions on this coastline (Bennett \& Pope 1953, 1960; O'Hara \& Poore 2000; Connell \& Irving 2008; Waters et al. 2010). If this hypothesis is correct, we predict that biota-wide endemic radiations in southern Australia marine fauna would frequently be characterized by a trident-like phylogeny, where three distinct lineages diverged within a relatively short period of time. Divergence times among the lineages may be taxon-specific, depending on when the respective lineages became established in southern Australia. We recommend that future studies focusing on marine diversification processes in southern Australia target all three provinces if possible and adopt model-based divergence time estimations to effectively test competing hypotheses. We also call attention to the possibility that contemporary ecological factors (e.g. SST) may sometimes stem from paleoclimatic processes and that their influence on lineage diversification can be long-term.

\section{Acknowledgements}

The authors thank the following people for supplying specimens: Maria Byrne, Don Colgan, Phil Colman, Emily Glover, Peter Middelfart and John Taylor. We thank the three anonymous reviewers and the following people for critically reading manuscript drafts: Catherine Badgley, Tomasz Baumiller, Thomas Duda, Taehwan Lee, Daniel Miller and Janice Pappas. This study is supported by a Malacological Society of Australasia Molluscan Research Grant and a Rackham International Research Award to JL and a National Science Foundation OCE award 0850625 to DÓF.

\section{References}

Alix B, Boubacar DA, Vladimir M (2012) T-REX: a web server for inferring, validating and visualizing phylogenetic trees and networks. Nucleic Acids Research, 40, W573-W579.

Appelbaum L, Achituv Y, Mokady O (2002) Speciation and the establishment of zonation in an intertidal barnacle: specific settlement vs. selection. Molecular Ecology, 11, 1731-1737.

Avise JC (1992) Molecular population structure and the biogeographic history of a regional fauna: a case history with lessons for conservation biology. Oikos, 63, 62-76.

Avise JC (2000) Phylogeography: The History and Formation of Species. Harvard University Press, Cambridge.

Baines PG, Edwards RJ, Fandry CB (1983) Observations of a new baroclinic current along the western continental slope of Bass Strait. Australian Journal of Marine and Freshwater Research, 34, 155-157.

Barber PH (2009) The challenge of understanding the Coral Triangle biodiversity hotspot. Journal of Biogeography, 36, 1845-1846.

Barber PH, Palumbi SR, Erdmann MV, Moosa MK (2002) Sharp genetic breaks among populations of Haptosquilla pulchella (Stomatopoda) indicate limits to larval transport: patterns, causes, and consequences. Molecular Ecology, 11, 659-674.

Barber PH, Erdmann MV, Palumbi SR (2006) Comparative phylogeography of three codistributed stomatopods: origins and timing of regional lineage diversification in the Coral Triangle. Evolution, 60, 1825-1839.

Bennett I, Pope EC (1953) Intertidal zonation of the exposed rocky shores of Victoria, together with a rearrangement of the biogeographical provinces of temperate Australian shores. Australian Journal of Marine and Freshwater Research, 4, 105-159.

Bennett I, Pope EC (1960) Intertidal zonation of the exposed rocky shores of Tasmania and its relationship with the rest of Australia. Australian Journal of Marine and Freshwater Research, 11, 182-221. 
Billingham M, Ayre DJ (1996) Genetic subdivision in the subtidal, clonal sea anemone Anthothoe albocincta. Marine Biology, 125, 153-163.

Bird E (1961) The coastal barriers of east Gippsland, Australia. The Geographical Journal, 127, 460-468.

Briggs JC (1974) Operation of zoogeographic barriers. Systematic Zoology, 23, 248-256.

Briggs JC, Bowen BW (2012) A realignment of marine biogeographic provinces with particular reference to fish distributions. Journal of Biogeography, 39, 12-30.

Brown LD (1991) Genetic variation and population stucture in the blacklip abalone, Haliotis rubra. Australian Journal of Marine and Freshwater Research, 42, 77-90.

Brown WM, George M, Wilson AC (1979) Rapid evolution of animal mitochondrial DNA. Proceedings of the National Academy of Sciences of the United States of America, 76, 1967-1971.

Burridge CP (2000) Biogeographic history of geminate cirrhitoids (Perciformes: Cirrhitoidea) with east-west allopatric distributions across southern Australia, based on molecular data. Global Ecology and Biogeography, 9, 517-525.

Caterino MS, Chatzimanolis S (2009) Conservation genetics of three flightless beetle species in southern California. Conservation Genetics, 10, 203-216.

Clement M, Posada D, Crandall KA (2000) TCS: a computer program to estimate gene genealogies. Molecular Ecology, 9, 1657-1659.

Colgan DJ, Costa P (2012) Possible drivers of biodiversity generation in the Siphonaria of southeastern Australia. Marine Biodiversity, Published online: DOI 10.1007/s12526-012-0127-2.

Colgan DJ, Schreiter S (2011) Extrinsic and intrinsic influences on the phylogeography of the Austrocochlea constricta species group. Journal of Experimental Marine Biology and Ecology, 397, 44-51.

Connell SD, Irving AD (2008) Integrating ecology with biogeography using landscape characteristics: a case study of subtidal habitat across continental Australia. Journal of Biogeography, 35, 1608-1621.

Darriba D, Taboada GL, Doallo R, Posada D (2012) jModelTest 2: more models, new heuristics and parallel computing. Nature Methods, 9, 772.

Dartnall AJ (1974) Littoral biogeography. In: Biogeography and Ecology in Tasmania (ed. Williams WD), pp. 171-194. Dr W Junk, The Hague.

Dawson MN (2005) Incipient speciation of Catostylus mosaicus (Scyphozoa, Rhizostomeae, Catostylidae), comparative phylogeography and biogeography in south-east Australia. Journal of Biogeography, 32, 515-533.

Drummond AJ, Suchard MA, Xie D, Rambaut A (2012) Bayesian phylogenetics with BEAUti and the BEAST 1.7. Molecular Biology and Evolution, 29, 1969-1973.

Duda TF, Lessios HA (2009) Connectivity of populations within and between major biogeographic regions of the tropical Pacific in Conus ebraeus, a widespread marine gastropod. Coral Reefs, 28, 651-659.

Ekman S (1953) Zoogeography of the Sea. Sidgwick and Jackson, London.

Excoffier L, Lischer HEL (2010) Arlequin suite ver 3.5: a new series of programs to perform population genetics analyses under Linux and Windows. Molecular Ecology Resources, 10, 564-567.

Faure B, Jollivet D, Tanguy A, Bonhomme F, Bierne N (2009) Speciation in the deep sea: multi-Locus analysis of diver- gence and gene flow between two hybridizing species of hydrothermal vent mussels. PLoS ONE, 4, e6485.

Flower BP, Kennett JP (1994) The middle Miocene climatic transition: East Antarctic ice sheet development, deep ocean circulation and global carbon cycling. Palaeogeography, Palaeoclimatology, Palaeoecology, 108, 537-555.

Forbes E (1856) Map of the distribution of marine life. In: The Physical Atlas of Natural Phenomena (ed. Johnston AK), pp. 99 -102 and plate 131. William Blackwood and Sons, Edinburgh.

Gallagher S, Smith A, Jonasson K et al. (2001) The Miocene palaeoenvironmental and palaeoceanographic evolution of the Gippsland Basin, Southeast Australia: a record of Southern Ocean change. Palaeogeography, Palaeoclimatology, Palaeoecolo$g y, \mathbf{1 7 2}, 53-80$.

Hasegawa M, Kishino H, Yano T (1985) Dating of the humanape splitting by a molecular clock of mitochondrial DNA. Journal of Molecular Evolution, 22, 160-174.

Hebert PDN, Stoeckle MY, Zemlak TS, Francis CM (2004) Identification of birds through DNA Barcodes. PLoS Biology, 2, e312.

Hedley C (1904) The effect of the Bassian Isthmus upon the existing marine fauna: a study in ancient geography. Proceedings of the Linnean Society of New South Wales, 28, 876-883.

Hidas EZ, Costa TL, Ayre DJ, Minchinton TE (2007) Is the species composition of rocky intertidal invertebrates across a biogeographic barrier in south-eastern Australia related to their potential for dispersal? Marine and Freshwater Research, 58, 835-842.

Holbourn A, Kuhnt W, Simo J, Li Q (2004) Middle Miocene isotope stratigraphy and paleoceanographic evolution of the northwest and southwest Australian margins (Wombat Plateau and Great Australian Bight). Palaeogeography, Palaeoclimatology, Palaeoecology, 208, 1-22.

Hutchins LW (1947) The bases for temperature zonation in geographical distribution. Ecological Monographs, 17, 325-335.

Jablonski D, Roy K, Valentine JW, Price RM, Anderson PS (2003) The impact of the pull of the recent on the history of marine diversity. Science, 300, 1133-1135.

James NP, Bone Y (2010) Neritic Carbonate Sediments in a Temperate Realm: Southern Australia. Springer, Dordrecht.

Kämpf J, Doubell M, Griffin D, Matthews RL, Ward TM (2004) Evidence of a large seasonal coastal upwelling system along the southern shelf of Australia. Geophysical Research Letters, 31, L09310.

Kassahn KS, Donnellan SC, Fowler AJ, Hall KC, Adams M, Shaw PW (2003) Molecular and morphological analyses of the cuttlefish Sepia apama indicate a complex population structure. Marine Biology, 143, 947-962.

Kessing B, Croom H, Martin A, Mcintosh C, Owen McmillanW, Palumbi S (1989) The Simple Fools Guide to PCR. University of Hawaii, Honolulu.

Knowlton N (1993) Sibling species in the sea. Annual Review of Ecology and Systematics, 24, 189-216.

Knox GA (1963) The biogeography and intertidal ecology of Australasian coasts. Oceanography and Marine Biology Annual Reviews, 1, 341-404.

Knox GA (1980) Plate tectonics and the evolution of intertidal and shallow-water benthic biotic distribution patterns of the southwest Pacific. Palaeogeography, Palaeoclimatology, Palaeoecology, 31, 267-297. 
Lambeck K, Chappell J (2001) Sea level change through the last glacial cycle. Science, 292, 679-686.

Lanfear R, Calcott B, Ho SYW, Guindon S (2012) PartitionFinder: combined selection of partitioning schemes and substitution models for phylogenetic analyses. Molecular Biology and Evolution, 29, 1695-1701.

Liu J-X, Gao T-X, Wu S-F, Zhang Y-P (2007) Pleistocene isolation in the Northwestern Pacific marginal seas and limited dispersal in a marine fish, Chelon haematocheilus (Temminck, Schlegel, 1845). Molecular Ecology, 16, 275-288.

Luiz OJ, Madin JS, Robertson DR, Rocha LA, Wirtz P, Floeter SR (2012) Ecological traits influencing range expansion across large oceanic dispersal barriers: insights from tropical Atlantic reef fishes. Proceedings of the Royal Society B: Biological Sciences, 279, 1033-1040.

Maddison WP (1997) Gene trees in species trees. Systematic Biology, 46, 523-536.

Marko PB (2002) Fossil calibration of molecular clocks and the divergence times of geminate species pairs separated by the Isthmus of Panama. Molecular Biology and Evolution, 19, 2005-2021.

McNeil SE (1994) The selection and design of marine protected areas: Australia as a case study. Biodiversity and Conservation, 3, 586-605.

Middleton JF, Bye JAT (2007) A review of the shelf-slope circulation along Australia's southern shelves: Cape Leeuwin to Portland. Progress In Oceanography, 75, 1-41.

Miglietta MP, Faucci A, Santini F (2011) Speciation in the sea: overview of the symposium and discussion of future directions. Integrative and Comparative Biology, 51, 449-455.

Mikkelsen PM (2011) Speciation in modern marine bivalves (Mollusca: Bivalvia): insights from the published record*. American Malacological Bulletin, 29, 217-245.

Moore WS (1995) Inferring phylogenies from mtDNA variation: mitochondrial-gene trees versus nuclear-gene trees. Evolution, 49, 718-726.

Munday PL, van Herwerden L, Dudgeon CL (2004) Evidence for sympatric speciation by host shift in the sea. Current Biology, 14, 1498-1504.

Ó Foighil D (1989) Planktotrophic larval development is associated with a restricted geographic range in Lasaea, a genus of brooding, hermaphroditic bivalves. Marine Biology, 103, 349-358.

Ó Foighil D, Jozefowicz CJ (1999) Amphi-Atlantic phylogeography of direct-developing lineages of Lasaea, a genus of brooding bivalves. Marine Biology, 135, 115-122.

Ó Foighil D, Smith MJ. (1995) Evolution of asexuality in the cosmopolitan marine clam Lasaea. Evolution, 49, 140-150.

Ó Foighil D, Smith MJ (1996) Phylogeography of an asexual marine clam complex, Lasaea, in the northeastern Pacific based on cytochrome oxidase III sequence variation. Molecular Phylogenetics and Evolution, 6, 134-142.

Ó Foighil D, Thiriot-Quievreux C (1999) Sympatric Australian Lasaea species (Mollusca: Bivalvia) differ in their ploidy levels, reproductive modes and developmental modes. Zoological Journal of the Linnean Society, 127, 477-494.

O'Hara TD, Poore GCB (2000) Patterns of distribution for southern Australian marine echinoderms and decapods. Journal of Biogeography, 27, 1321-1335.

Palumbi SR (1994) Genetic divergence, reproductive isolation, and marine speciation. Annual Review of Ecology and Systematics, 25, 547-572.
Posada D (2008) jModelTest: phylogenetic model averaging. Molecular Biology and Evolution, 25, 1253-1256.

Puebla O (2009) Ecological speciation in marine v. freshwater fishes. Journal of Fish Biology, 75, 960-996.

Rambaut A, Drummond AJ (2009) Tracer v. 1.5. Computer program and documentation distributed by the authors. Available at: http:/ / tree.bio.ed.ac.uk/software/tracer/

Ravelo AC, Andreasen DH, Lyle M, Olivarez Lyle A, Wara MW (2004) Regional climate shifts caused by gradual global cooling in the Pliocene epoch. Nature, 429, 263-267.

Reeb CA, Avise J (1990) A genetic discontinuity in a continuously distributed species: mitochondrial DNA in the American oyster, Crassostrea virginica. Genetics, 124, 397-406.

Ridgway K, Hill K (2009) The East Australian Current. In: A Marine Climate Change Impacts and Adaptation Report Card for Australia 2009 (eds Poloczanska ES, Hobday AJ, Richardson AJ), pp. 1-16. National Climate Change Adaptation Research Facility, Gold Coast, Australia.

Riginos C, Nachman MW (2001) Population subdivision in marine environments: the contributions of biogeography, geographical distance and discontinuous habitat to genetic differentiation in a blennioid fish, Axoclinus nigricaudus. Molecular Ecology, 10, 1439-1453.

Roberts D (1984) A comparative study of Lasaea australis, Vulsella spongiarum, Pinna bicolor and Donacilla cuneata (Mollusca; Bivalvia) from Princess Royal Harbour, Western Australia. Journal of Molluscan Studies, 50, 129-136.

Rochford DJ (1986) Seasonal changes in the distribution of Leeuwin Current waters off Southern Australia. Australian Journal of Marine and Freshwater Research, 37, 1-10.

Ronquist F, Huelsenbeck JP (2003) MrBayes 3: Bayesian phylogenetic inference under mixed models. Bioinformatics, 19, 1572-1574.

Ronquist F, Teslenko M, van der Mark P et al. (2012) MrBayes 3.2: efficient Bayesian phylogenetic inference and model choice across a large model space. Systematic Biology, 61, 539-542.

Rowe FEW, Vail LL (1982) The distribution of Tasmanian echinoderms in relation to southern Australian biogeographic provinces. In: Echinoderms, Proceedings of the International Conference, Tampa Bay (ed. Lawrence JM), pp. 219-225. Balkema, Rotterdam.

Rundle HD, Nosil P (2005) Ecological speciation. Ecology Letters, 8, 336-352.

Sánchez JA, Dorado D (2008) Intragenomic ITS2 variation in Caribbean seafans. In: Proceedings of the 11th International Coral Reef Symposium 2:, pp. 1383-1387. Ft. Lauderdale, Florida.

Schluter D (2001) Ecology and the origin of species. Trends in Ecology \& Evolution, 16, 372-380.

Schopf TJM (1979) The role of biogeographic provinces in regulating marine faunal diversity through geologic time. In: Historical Biogeography, Plate Tectonics, and the Changing Environment (edsGray J, Boucot AJ), pp. 449-457. Oregon State University Press, Corvallis, Oregon.

Shevenell AE, Kennett JP, Lea DW (2004) Middle Miocene Southern Ocean cooling and Antarctic cryosphere expansion. Science, 305, 1766-1770.

Spalding MD, Fox HE, Allen GR et al. (2007) Marine ecoregions of the world: a bioregionalization of coastal and shelf areas. BioScience, 57, 573-583. 
Stamatakis A, Hoover P, Rougemont J (2008) A rapid bootstrap algorithm for the RAxML Web servers. Systematic Biology, 57, 758-771.

Stephens M, Smith NJ, Donnelly P (2001) A new statistical method for haplotype reconstruction from population data. American Journal of Human Genetics, 68, 978-989.

Tamura K (1992) Estimation of the number of nucleotide substitutions when there are strong transition-transversion and $\mathrm{G}+\mathrm{C}-\mathrm{content}$ biases. Molecular Biology and Evolution, 9, 678687.

Tamura K, Nei M (1993) Estimation of the number of nucleotide substitutions in the control region of mitochondrial DNA in humans and chimpanzees. Molecular Biology and Evolution, 10, 512-526.

Tamura K, Peterson D, Peterson N, Stecher G, Nei M, Kumar S (2011) MEGA5: Molecular Evolutionary Genetics Analysis using maximum likelihood, evolutionary distance, and maximum parsimony methods. Molecular Biology and Evolution, 28, 2731-2739.

Taylor DJ, Ó Foighil D (2000) Transglobal comparisons of nuclear and mitochondrial genetic structure in a marine polyploid clam (Lasaea, Lasaeidae). Heredity, 84, 321-330.

Teske PR, Winker H, McQuaid C, Barker N (2009) A tropical/ subtropical biogeographic disjunction in southeastern Africa separates two Evolutionarily Significant Units of an estuarine prawn. Marine Biology, 156, 1265-1275.

Teske PR, Papadopoulos I, Mmonwa KL et al. (2011) Climatedriven genetic divergence of limpets with different life histories across a southeast African marine biogeographic disjunction: different processes, same outcome. Molecular Ecology, 20, 5025-5041.

Thompson JD, Higgins DG, Gibson TJ (1994) CLUSTAL W: improving the sensitivity of progressive multiple sequence alignment through sequence weighting, position-specific gap penalties and weight matrix choice. Nucleic Acids Research, 22, 4673-4680.

Tong L (1990) The Population Ecology of the Intertidal Bivalve Lasaea australis. Ph. D. Thesis, The University of Sydney, Sydney.

Vierna J, Martínez-Lage A, González-Tizón AM (2010) Analysis of ITS1 and ITS2 sequences in Ensis razor shells: suitability as molecular markers at the population and species levels, and evolution of these ribosomal DNA spacers. Genome, 53, 23-34.

Waters JM (2008) Marine biogeographical disjunction in temperate Australia: historical landbridge, contemporary currents, or both? Diversity and Distributions, 14, 692-700.

Waters JM, Roy MS (2003) Marine biogeography of southern Australia: phylogeographical structure in a temperate seastar. Journal of Biogeography, 30, 1787-1796.

Waters JM, O'Loughlin PM, Roy MS (2004) Cladogenesis in a starfish species complex from southern Australia: evidence for vicariant speciation? Molecular Phylogenetics and Evolution, 32, 236-245.

Waters JM, King TM, O'Loughlin PM, Spencer HG (2005) Phylogeographical disjunction in abundant high-dispersal littoral gastropods. Molecular Ecology, 14, 2789-2802.

Waters JM, Wernberg T, Connell SD et al. (2010) Australia's marine biogeography revisited: Back to the future? Austral Ecology, 35, 988-992.
Wiens JJ, Kuczynski CA, Stephens PR (2010) Discordant mitochondrial and nuclear gene phylogenies in emydid turtles: implications for speciation and conservation. Biological Journal of the Linnean Society, 99, 445-461.

Wilke T, Schultheiß R, Albrecht C (2009) As time goes by: a simple fool's guide to molecular clock approaches in invertebrates. American Malacological Bulletin, 27, 25-45.

Wilson BR, Allen GR (1987) Major components and distribution of marine fauna. In: Fauna of Australia (eds Dyne GR, Walton DW), pp. 43-68. Australian Government Publishing Service, Canberra.

Xu Z, Guo X, Gaffney PM, Pierce JC (2001) Chromosomal location of the major ribosomal RNA genes in Crassostrea virginica and Crassostrea gigas. Veliger, 44, 79-83.

York KL, Blacket MJ, Appleton BR (2008) The Bassian Isthmus and the major ocean currents of southeast Australia influence the phylogeography and population structure of a southern Australian intertidal barnacle Catomerus polymerus (Darwin). Molecular Ecology, 17, 1948-1961.

Zink RM, Barrowclough GF (2008) Mitochondrial DNA under siege in avian phylogeography. Molecular Ecology, 17, 21072121.

D.Ó.F., J.L. and J.K.P. designed the study. D.Ó.F. and J.L. sampled the specimens. J.L. and J.K.P. generated the molecular data. J.L. performed the molecular analyses. D.Ó.F. and J.L. wrote the paper.

\section{Data accessibility}

DNA sequences: GenBank Accessions JX910453JX910524.

Phylogenetic data: TreeBASE Study Accession No. 13724.

Specimen information: uploaded as Table S1.

\section{Supporting information}

Additional supporting information may be found in the online version of this article.

Table S1 Excel file with detailed specimen collecting information and GenBank Accession numbers.

Table S2 Excel file with Australian Museum records of Lasaea australis. The lowest latitude Eastern and Western records are highlighted.

Fig. S1 PDF file of the complete Bayesian and ML16S phylogenies of Lasaea australis.

Fig. S2 PDF file of the inferred paleodistributions of the three clam lineages during the Last Glacial Maximum. 